\title{
SEWAGE IMPACT ON THE COMPOSITION AND DISTRIBUTION OF POLYCHAETA ASSOCIATED TO INTERTIDAL MUSSEL BEDS OF THE MAR DEL PLATA ROCKY SHORE, ARGENTINA
}

\author{
Rodolfo Elías ${ }^{1}$ \\ María Silvia Rivero ${ }^{1}$ \\ Eduardo Alberto Vallarino ${ }^{1}$
}

\begin{abstract}
The polychaete composition and distribution within mussel beds were studied in order to assess organic pollution due to domestic sewage in a rocky shore of Mar del Plata (Argentina) during 1997. Four stations and a control site were randomly sampled around the local effluent. Quantitative data on polychaetes, as well as sediment accumulated among mussels and its organic carbon content were measured. Polychaete distribution patterns are related to the organic matter gradient, being Capitella cf. capitata, Neanthes succinea (Frey \& Leuckart, 1847) and Boccardia polybranchia (Haswell, 1885) the dominant indicator species close to the effluent. At medial distances, the cirratulids Caulleriella alata (Southern, 1914) and Cirratulus cirratus (Müller, 1776) are very important in abundance. The syllids Syllis prolixa Ehlers, 1901 and S. gracilis Grube, 1840 are distributed along the study area, but dominate at the medial stations and at the control site. The orbiniid Protoariciella uncinata Hartmann-Schröder, 1962 is subdominant at the control station.
\end{abstract}

KEYWORDS. Polychaeta, intertidal, mussel beds, sewage, Southwestern Atlantic.

\section{INTRODUCTION}

Biological communities have been seen as effective tools for assessing sewage pollution. Macrobenthic animals are easy to monitor, because they can be sampled quantitatively and also respond to man-made disturbance (Отшау et al., 1996). Organic enrichment of sediments due to sewage may result in a series of non-linear changes in the abundance, biomass and diversity of benthic organisms, in both spatial and temporal patterns (Pearson \& Rosenberg, 1978). Polychaetes are one of the most useful marine organisms to detect pollution because they live at the water-sediment interface. This layer is biologically reactive and chemically active (RHOADS \& BOYER, 1982). Polychaetes have been used in bioassays, to monitor toxic compounds, and as pollution indicators, from community or populational levels to species level (PockLington \& WeLLs, 1992; ReISH \& GERLINGER, 1997). The presence or absence of some indicator species or even families are currently known as pollution indicators, in particular the presence of Capitella

1. Departamento de Ciencias Marinas, Universidad Nacional de Mar del Plata, Deán Funes 3350, B 7602 AYL, Mar del Plata, Argentina. (roelias@mdp.edu.ar) 
capitata (Fabricius, 1780) or some spionids (Tsutsumi, 1990), or the absence of the genus Lumbrineris Blainville, 1828 (RYGGS, 1985).

In the southwestern Atlantic shore, sewage is discharged into the shallow waters or intertidal areas, like in the Mar del Plata $\left(38^{\circ} \mathrm{S} ; 57^{\circ} \mathrm{W}\right)$, Argentina. The city (with about 550,000 inhabitants) needs a way to evaluate the extent and degree of this impact because it is the major seaside resort of the country, receiving more than 2,000,000 people during the summer. The intertidal zone in the Mar del Plata area is constituted by extense sandy beaches (without macrofauna) and rocky shores (quartzitic outcrops and platforms of caliche). Arround the sewage effluent, the intertidal zone comprises abrasion platforms inhabited by mussel beds made up by the mytilid Brachidontes rodriguezii (Orbigny, 1846). The community structure of these epilithic mussel beds has been successfully used to detect the environmental impact due to domestic sewage (LóPEZ GAPPA et al., 1990). The monitoring using community-level information is expensive in terms of menhours needed to identify and count all organisms living in the mussel community. The study of the mussel-associated flora and fauna could be suitable for assessing organic enrichment due to domestic sewage in the Argentine coast (LÓPEZ GAPPA et al., 1993). The mussel matrix creates sedimentary microhabitats that are occupied by small invertebrates, including several polychaetes (Penchaszadeh, 1973; TsuchiYa \& NishinIRA, 1985; JaCobi, 1987; Günther, 1996; Scelzo et al., 1996; Svane \& Setyobudiandi, 1996; RAGNARSSON \& RAFFAELLI, 1999). However, no quantitative data about polychaete pattern are available from the southwestern Atlantic shore.

In order to assess the sewage impact on this hard-bottom intertidal area, a spatial study of the polychaete species associated with mussel beds was conducted.

\section{MATERIAL AND METHODS}

The sampling area is an open coast exposed to a longshore littoral current (South to North) and autumn-winter storms. Extensive sandy beaches alternate with quartzitic outcrops and abrasion platforms. Around the sewage effluent, an abrasion platform is exposed to low tides, being azoic in the North (except for a few opportunistic algae), and covered by a mytilid community in the South (the sampling area). These platforms are hard substrates of caliche (consolidate loess), characterized by an irregular and gradual slope (almost horizontal). Grooves lying perpendicular to the shoreline are common. Semidiurnal tides vary between 0.61 and $0.91 \mathrm{~m}$ (IsLA \& FerRanTe, 1997). Energy waves are high (mean height of $0.91 \mathrm{~m}$ ) reaching a maximum of $2.3 \mathrm{~m}$ during storms (LANFREDI et al., 1992). The coastal area of Mar del Plata is characterized by the presence of Continental Shelf Waters, with seawater temperature ranging from 8 to $21^{\circ} \mathrm{C}$, and salinity from 33.5 to 33.8 psu (Guerrero \& Piola, 1997).

Four locations, from $50 \mathrm{~m}$ (station 1) up to $700 \mathrm{~m}$ (station 4) south of the effluent, were sampled during November 1997 (fig. 1). Sampling was performed in each station at two levels, superior (exposed in neap tides) and inferior (only exposed in spring tides), except for station 1 (the closest to the effluent) due to the absence of the inferior level. At each level, four sampling units were randomly obtained with a $78 \mathrm{~cm}^{2}$ corer (diameter: $10 \mathrm{~cm}$ ). A control site (station C) was also sampled in the Santa Elena Formation (also an abrasion platform) placed $9 \mathrm{~km}$ north of the effluent. Each sampling unit was sieved $(1 \mathrm{~mm})$, and the associate polychaetes living on and among mussels were studied. Polychaete identification follows Fauchald (1977) and specific papers. Sediments accumulated among mussels were retained for total weight in each sampling unit, and their total organic Carbon content (\%) was determined from subsamples (WALKLEY \& BLACK, 1965).

Data were analyzed using analysis of Variance (ANOVA). Biological and environmental data were transformed (double square root) to increase homocedasticity of variances. Only eight polychaete taxa were normally distributed before transformation (tab. I), and were used to test differences between tidal levels (superior-inferior). The sampling units were then pooled for a two-way ANOVA, 


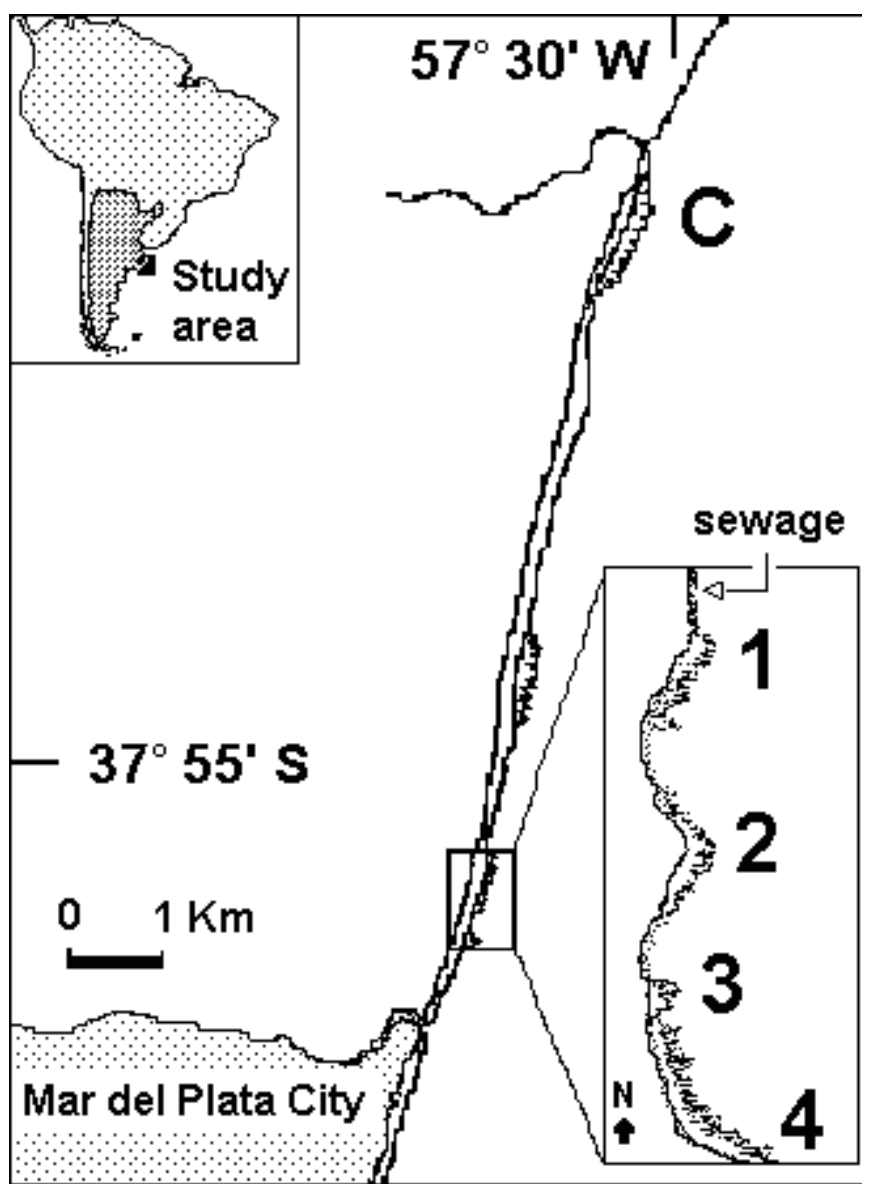

Fig. 1. Sampling area and sampling stations in intertidal mussel beds developed in abrasion platforms (hard substrate) around the sewage effluent of Mar del Plata $\left(38^{\circ} \mathrm{S} ; 57^{\circ} \mathrm{W}\right)$.

in which station is the fixed factor and the abundance of polychaetes the categorical predictor variable. Differences in total organic Carbon and sediment among mussels were tested by an one-way ANOVA. Whenever a difference was established, a post-hoc SNK test was performed to the appropriate alpha level. The relationship between the biological and the environmental variables was analyzed with Redundancy analysis (RDA), and a simple Regression analysis was performed for each polychaete species and total organic Carbon (Jongman et al., 1995). The material is deposited in the laboratory of Bioindicadores Bentónicos, Departamento de Ciencias Marinas, Universidade Nacional de Mar del Plata.

\section{RESULTS}

Sediments accumulated among mussels increased from the effluent to the control station (fig. 2). Total organic Carbon was high at the stations 1 and 2 (from 50 to $230 \mathrm{~m}$ ), but low at the stations 3 and $4(>450 \mathrm{~m}$ ) and at the control station (fig. 3). Differences in both parameters were highly significant $(p<0.01)$ between stations $1-2$ and the other stations. 


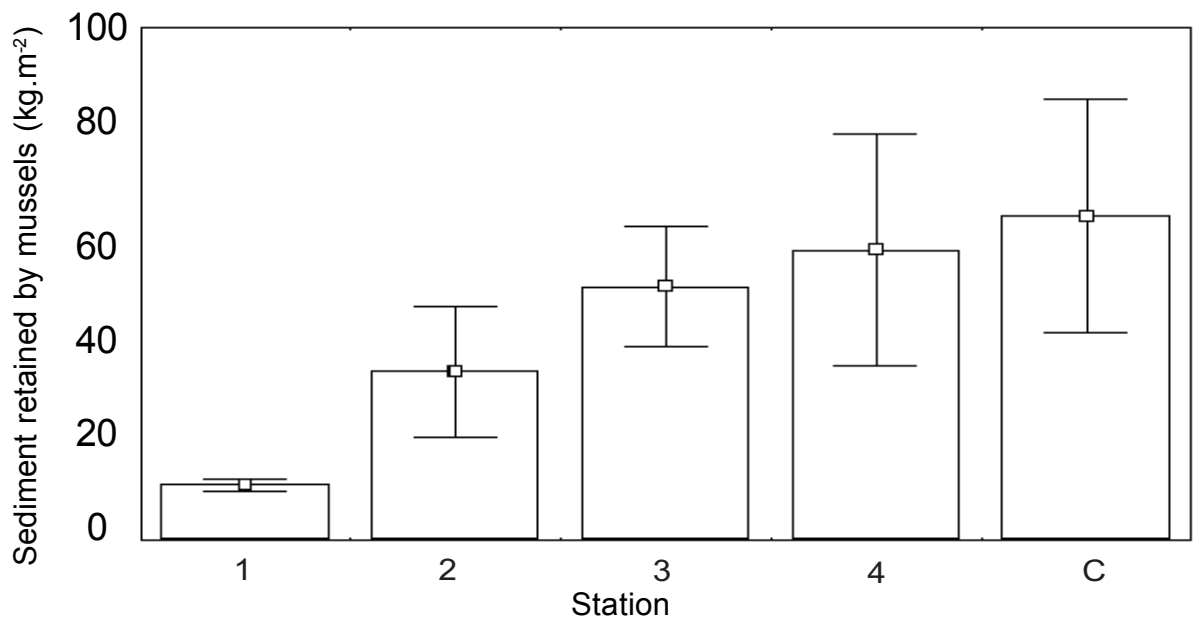

Fig. 2. Mean ( $\pm \mathrm{sd})$ of sediments among mussels $\left(\mathrm{kg} \cdot \mathrm{m}^{-2}\right)$ in each sampling station.

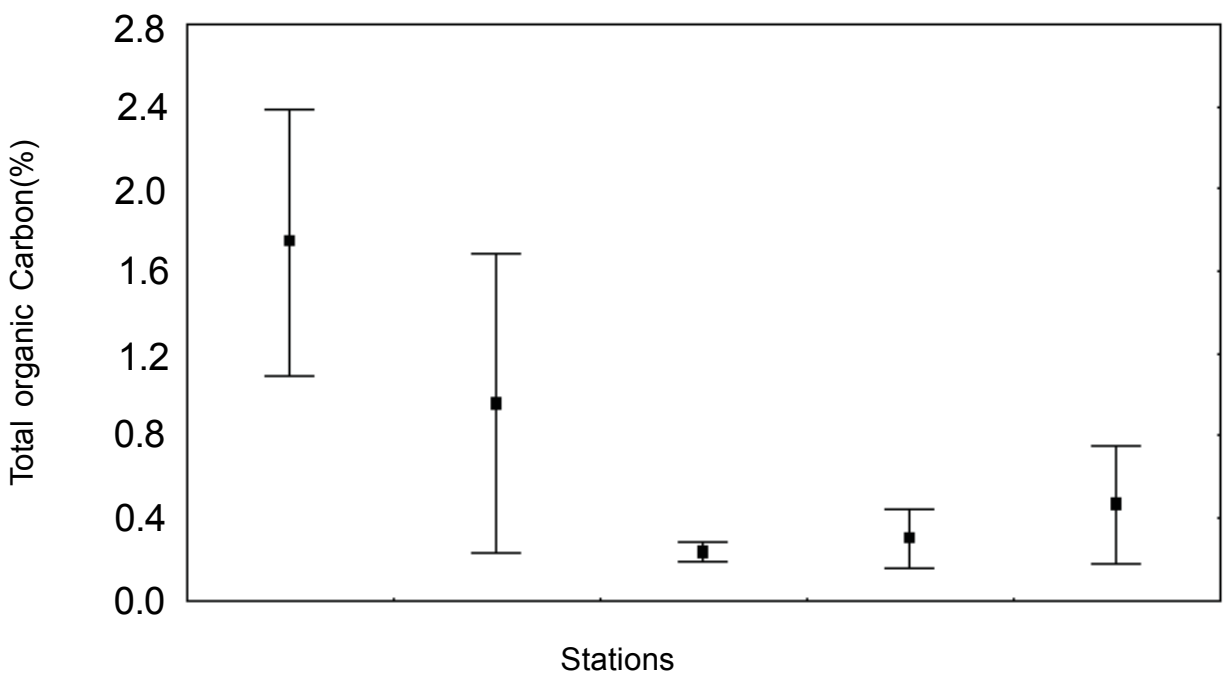

Fig. 3. Mean ( \pm sd) of total organic Carbon (\%) in each sampling station.

A total of 5,098 individuals belonging to 18 species were identified (tab. I). Polychaete dominance ranged from 7.7 to $37.7 \%$ of the community, these extreme values corresponding respectively to station $\mathrm{C}$ (control) and station 1 (the closest to the effluent) (fig. 4). 
Table I. Polychaetes and their dominance (\%) in the intertidal mussel beds of the mytilid Brachidontes rodriguezii community in the Mar del Plata shore, Argentina, during 1997. The marked species $(\checkmark)$ present normal distribution before transformation and were used in the analysis.

\begin{tabular}{|c|c|}
\hline & $\begin{array}{c}\text { Dominance } \\
(\%)\end{array}$ \\
\hline Syllis prolixa Ehlers, 1901 & $\checkmark 65.20$ \\
\hline Syllis gracilis Grübe, 1840 & $\checkmark 12.00$ \\
\hline Protoariciella uncinata Hartmann-Schröder, 1962 & $\checkmark \quad 5.88$ \\
\hline Boccardia polybranchia (Haswell, 1885) & $\checkmark \quad 5.62$ \\
\hline Caulleriella alata (Southern, 1914) & $\checkmark \quad 4.28$ \\
\hline Capitella cf. capitata & $\checkmark \quad 3.57$ \\
\hline Cirratulus cirratus (Müller, 1776) & $\checkmark \quad 2.03$ \\
\hline Boccardia chilensis Hartman, 1940 & 0.65 \\
\hline Neanthes succinea (Frey \& Leuckart, 1847) & $\checkmark \quad 0.28$ \\
\hline Syllis sp.1 & 0.12 \\
\hline Spionidae unidentified & 0.06 \\
\hline Dodecaceria concharum Oested, 1843 & 0.06 \\
\hline Syllis sp.2 & 0.04 \\
\hline Glycera americana Leidy, 1855 & 0.04 \\
\hline Lumbrineris tetraura $($ Schmarda, 1861$)$ & 0.04 \\
\hline Phyllodocidae & 0.04 \\
\hline Paleanotus intermedius Orensanz, 1972 & 0.04 \\
\hline Heteromastus similis (Claparède, 1864) & 0.04 \\
\hline
\end{tabular}

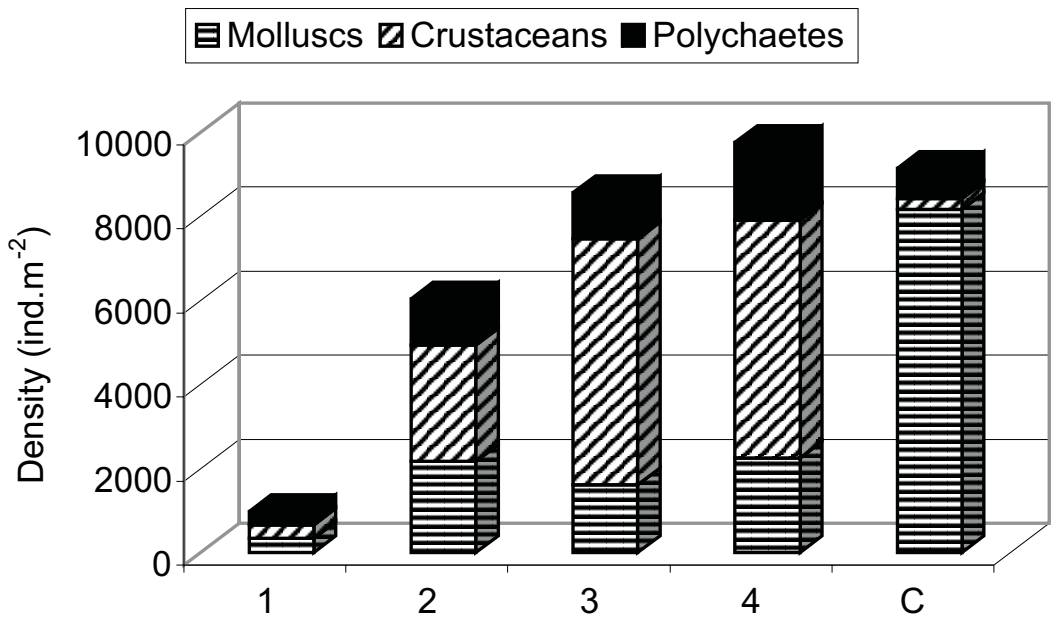

Fig. 4. Mean density and proportion of macroorganisms in the intertidal area affected by domestic sewage effluent from the city of Mar del Plata $\left(38^{\circ} \mathrm{S} ; 57^{\circ} \mathrm{W}\right)$. Organic gradient decreases from Station 1 to 4 . Station $\mathrm{C}$ (control) is situated $9 \mathrm{~km}$ north.

A first one-way ANOVA was performed to test differences between tidal levels, superior and inferior, and proved to be not significant. Sampling units were therefore pooled for a two-way ANOVA considering stations and polychaetes as factors. The 
Table II. Two-way analysis of variance (ANOVA) considering station as fixed factor and abundance of polychaetes as categorical predictor variable. Polychaete species considered: Neanthes succinea, Boccardia polybranchia, Capitella cf. capitata, Cirratulus cirratus, Caulleriella alata, Syllis prolixa, Syllis gracilis and Protoariciella uncinata $\left({ }^{*} \mathrm{p}<0.05\right)$.

\begin{tabular}{lcccccc}
\hline & df Effect & MS Effect & df Error & MS Error & F & p-level \\
\hline Station & 4 & 4.61122 & 31 & 0.203576 & 22.6511 & $0.000000^{*}$ \\
Polychaetes & 7 & 19.12289 & 217 & 0.155417 & 123.042 & $0.000000^{*}$ \\
Interaction & 28 & 3.36003 & 217 & 0.155417 & 21.6194 & $0.000000^{*}$ \\
\hline
\end{tabular}

results showed that differences between both stations and polychaetes were significant, as well as differences due to interactions (tab. II).

Interactions between stations and polychaete distribution patterns (fig. 5) show the different behavior according to distance from effluent. Capitella cf. capitata, Neanthes succinea and Boccardia polybranchia were dominant near the outfall (station 1 , and in minor degree in station 2$)$. These species had positive and significant $(\mathrm{p}<0.05)$ correlation coefficients for total organic Carbon $\left(\mathrm{r}^{2}=0.4312,0.3905\right.$, and 0.1412 , respectively). Dominance of syllids (Syllis prolixa and S. gracilis) was inversely correlated to the distance from the effluent, and only diminished by the presence of a great abundance
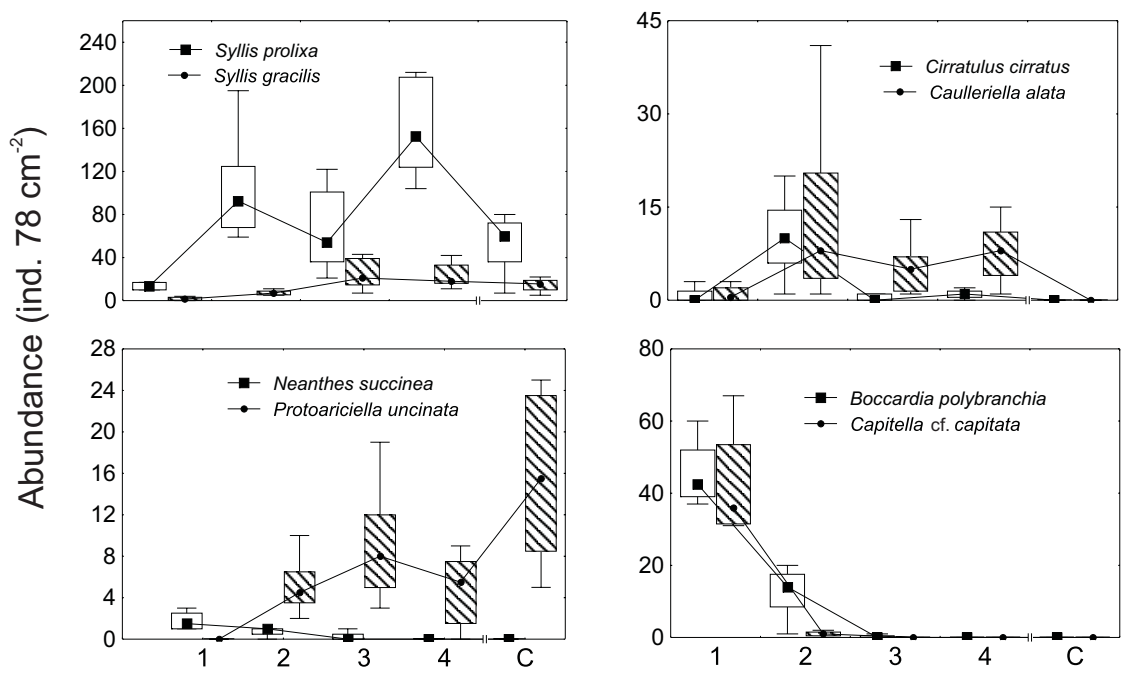

Stations

Fig. 5. Abundance (black dot represents the median value, box represents the 25 and $75 \%$ percentiles, and the bar 10 and $90 \%$ percentiles) of the main polychaete species associated to the intertidal community of the mytilid Brachidontes rodriguezii. Organic gradient decreases from 1 to 4. Station $\mathrm{C}$ (control) is $9 \mathrm{~km}$ north to the effluent. 
of Protoariciella uncinata in the control station (C). The former species had negative and significant $(\mathrm{p}<0.05)$ correlation coefficients for total organic Carbon $\left(\mathrm{r}^{2}=-0.1566,-0.2606\right.$, and -0.3447 respectively). At medial distances the cirratulids Caulleriella alata and Cirratulus cirratus were sub dominant, with low and non-significant correlation coefficients.

Redundancy analysis (fig. 6) showed the existence of two major and opposite gradients along axis I, one of increasing amount of total organic Carbon from the control site to the outfall, and other of increasing sediment accumulated among mussels, with an opposite trend. The closest stations to the effluent were highly related to positive values of the first gradient, as well as the species $C$. cf. capitata, N. succinea and B. polybranchia, while the control station $(\mathrm{C})$ was highly related to the negatives values, associated to $P$. uncinata and syllids. Axis I explained $97.2 \%$ of the total variance, and represents the organic enrichment gradient. Axis II explained $2.8 \%$ of the variance and is apparently related to species richness, which is high at medial stations (positive values).

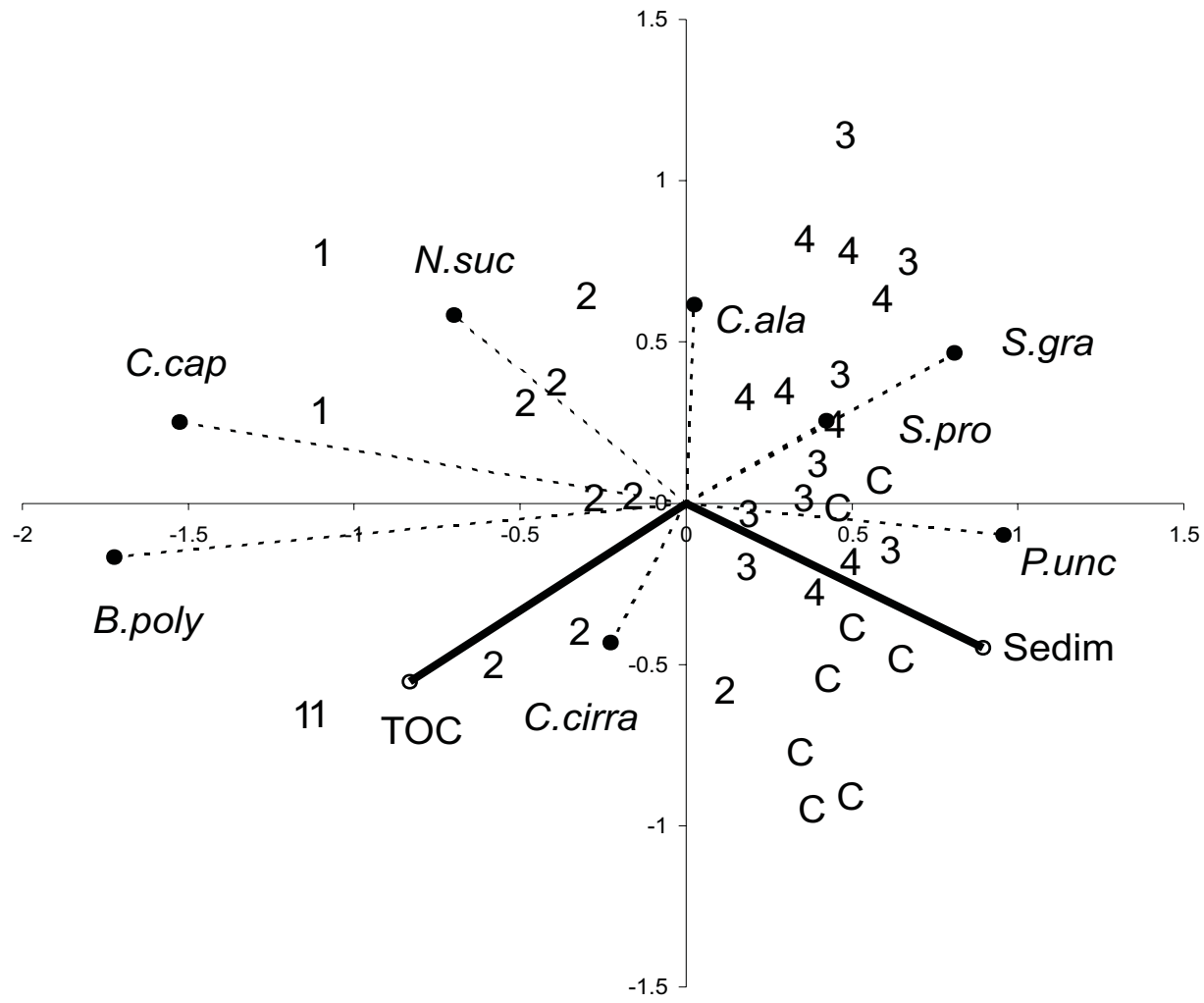

Fig. 6. Redundancy analysis on sampling units, species and environmental variables in the intertidal mussel beds exposed to sewage discharge from the city of Mar del Plata (Sedim, sediment accumulated among mussels; TOC, total organic Carbon; C. cap, Capitella ef. capitata; C. cirra, Cirratulus cirratus; N. suc, Neanthes succinea; B. poly, Boccardia polybranchia; C. ala, Caulleriella alata; S. pro, Syllis prolixa; S. gra, Syllis gracilis; P. unc, Protoariciella uncinata). 


\section{DISCUSSION}

Spionid and capitellid polychaetes in general, and the Capitella complex in particular, have largely been used as classical indicators of organically enriched sediments (Reish, 1972; Tsutsumi, 1990; Pocklington \& Wells, 1992). In Denmark, the dominance of C. capitata and Polydora ciliata Webster, 1879 among Mytilus edulis L., 1758 banks was related to the local hydrodynamics, affecting sedimentation or increasing faeces and pseudofaeces of mussels (Svane \& Setyobudiandi, 1996). In the intertidal abrasion platform around Mar del Plata sewage effluent, the distribution pattern of $C$. cf. capitata is clearly related to the gradient of organic pollution. The same can be stated for the dominant spionid B. polybranchia in the station near the effluent. The use of some spionids (Polydora ciliata and other congeneric species and other genera) also indicates sediments organically enriched (PEARSON \& ROSENBERG, 1978). In another southern abrasion platform affected by sewage, LóPEz GAPPA et al. (1990) found high densities of Boccardia sp. (about 500,000 ind. $\mathrm{m}^{-2}$ ) associated to sand banks and also among Brachidontes Swainson, 1840 beds. Boccardia proboscidea Hartman, 1940 was found primarily in large abundance in the intertidal zone of an outfall area in California, USA (Dorsey et al., 1983) and also in an Australian sewage (Dorsey, 1982).

The cirratulids Cirratulus cirratus and Caulleriella alata are present at medial stations. Some cirratulids were also mentioned as indicators of organically enriched sediments, like Cirriformia spp. associated to Capitella capitata, Scolelepis Blainville, 1828 or Polydora Bosc, 1802, in or near polluted areas (PeArson \& Rosenberg, 1978). Species of the genus Tharyx Webster \& Benedict, 1887 may be extremely abundant in polluted areas (FAuchald \& Jumars, 1979; Dorsey et al., 1983). Around the effluent of domestic sewage in the northwest of Mediterranean Sea, C. cirratus was found in association to subtidal mytilid beds, being considered as tolerant to organic pollution (BITAR, 1982). No records of great abundances of cirratulids from the southern mytilid beds were reported before, suggesting that these two species could indicate an opportunist enrichment.

Neanthes succinea, formely mentioned for mixohaline waters (ORENSANZ \& Estivariz, 1971), was cited as associated to Brachidontes rodriguezii community in vertical substrates (ScElzo et al., 1996). Although Neanthes Linnaeus, 1758 species have been found in or around organically polluted zones (PEARSON \& ROSENBERG, 1978), this is the first mention for $N$. succinea in the SW Atlantic shore in relation to an organic gradient.

Syllids are typical inhabitants of this intertidal community (OLIVIER et al., 1966; Penchaszadeh, 1973), being indicators of the high and mid eulittoral in vertical substrates (Scelzo et al., 1996). However, in abrasion platforms (corresponding to the low eulitoral) affected by sewage, their abundance and dominance reach high values at medial distances from the effluent, but show a negative relationship with the organic matter. The most common species is Syllis prolixa, followed by S. gracilis.

The orbiniid Protoariciella uncinata is subdominant at the control Station, decreasing towards the effluent, and disappearing in the most impacted station. They also show a negative correlation with the organic matter. This species was cited before in other mytilids beds of Chile and Peru (HARTMANN-SCHRÖDER, 1962a, b), but in the Pacific Ocean it is considered as an indicator of organically enriched sediments (ELÍAs et al., 2000). 
The two gradients observed in the Redundancy analysis from the outfall could be synthesized in only one, the amount of organic matter, because the sediments accumulated among mussels in a density-dependent variable are related to the population dynamics of the mytilids. The density of Brachidontes rodriguezii increases from the outfall to the control site, as well as the presence of juveniles (VALLARINO et al., 2002). This phenomenon produces the matrix that traps the sediments (GosLing, 1992). As a result of this increasing sewage impact, mytilid density decreases towards the effluent, resulting in a decrease of trapped sediments.

This is the first comprehensive and quantitative study of the polychaetes associated to mussel beds in this part of the southwestern Atlantic shore. Although the data are limited to the spatial scale, other results show that this trend is also present at the time scale, in both the short-term and the long-term period. The present study confirms that polychaetes are useful tool to assess sewage impact in the hard-bottom rocky shores of the southwestern Atlantic.

Acknowledgements. To Dr. V. Radashevsky (Centro de Estudos do Mar, UFPR, Brazil) for identification of spionids. Dra. C. Bremec (CONICET, INIDEP) also contributed to polychaete identification. To Obras Sanitarias Sociedad de Estado (OSSE) for partial funding to the project. Dr. O. Iribarne (UNMdP, Argentina) and Dr. P. Lana (UFPR) for valuable comments, which improved the manuscript, as well as other anonymous reviewer. Lic. L. Sousa revised the english version.

\section{REFERENCES}

BitaR, G. 1982. Influence d'un grand émisaire urbain sur la distribution du zoobenthos de substrate dur dans la région de Marseille (Mediterranée Nord-occidentale). Tethys, Paris, 10(3):200-210.

Dorsey, J. H. 1982. Intertidal community offshore from the Werribee sewage-treatment farm: an opportunistic infaunal assemblage. Aust. J. mar. Freshwat. Res., Sydney, 33:45-54.

Dorsey, J. H.; Green, K. D. \& Rowe, R. C. 1983. Effects of sewage disposal on the polychaetous Annelids at San Clemente Island, California. In: Soule, D. F. \& Walsh, D. eds. Waste disposal in the oceans. Minimizing impact, maximizing benefits. Los Angeles, University of Southern California. c. 13, p.209-233.

Elías, R.; Vallarino, E. A. \& Bremec, C. S. 2000. Protoariciella uncinata Hartmann-Schröeder, 1962 (Polychaeta, Orbiniidae): a new record for intertidal mussel beds of the southwestern Atlantic shore affected by sewage effluents. Revta Biol. mar. Oceanogr., Valparaiso, 35(2):181-184.

Fauchald, K. 1977. The polychaete worms. Definitions and keys to orders, families and genera. Nat. Hist. Mus. Los Angeles County Allan Hancock Found., Science Series, Los Angeles, 28:1188.

Fauchald, K. \& Jumars, P. A. 1979. The diet of worms: a study of polychaetes feeding guilds. Oceanogr. Mar. Biol. Ann. Rev., Aberdeen, 17:193-284.

GosLing, E. 1992. The mussel Mytilus: ecology, physiology, genetics and culture. Amsterdam, Elsevier Science Publ. 588p.

Guerrero, R. A. \& Piola, A. R. 1997. Masas de agua en la plataforma continental. In: Boschi, E. E. ed. El mar Argentino y sus recursos pesqueros 1. Mar del Plata, Instituto Nacional de Investigación y Desarrollo Pesquero. p.107-118.

GüNTHER, C. P. 1996. Development of small Mytilus beds and its effects on resident intertidal macrofauna. P.S.Z.N.I. Mar. Ecol., Napoles, 17:117-130.

Hartmann-Schröder, G. 1962a. Zweiter beitrag zur Polychaetenfauna von Peru. Kieler Meeresforsch., Kiel, 18:109-147.

1962b. Die Polychaeten des Eulittorals. Zur kenntnis des Eulittorals der Chilenischen Pazifikkuste und der Argentinischen Kust Sudpatagoniens unter besonderer Berucksichtigung der Polychaeten und Ostracoden. Mitt. hamb. zool. Mus. Inst., Hamburg, 60(Suppl.):57-167.

Isla, F. I. \& Ferrante, A. 1997. Corrientes. In: Ilsa, F. I. ed. Estudio del sector de plataforma receptor de la descarga cloacal de Camet, Mar del Plata. Mar del Plata, Facultad de Ciencias 
Exactas y Naturales. p.63-116.

JACOBI, C. M. 1987. The invertebrate fauna associated with intertidal beds of the brown mussel Perna perna (L.) from Santos, Brazil. Stud. Neotrop. Fauna Environ., Lisse, 22:57-72.

Jongman, R. H. G.; Ter BraAk, C. J. F. et al. 1995. Data analysis in community and landscape ecology. Cambridge, Cambridge University. 194p.

Lanfredi, N. W.; Pousa, J. L. et al. 1992. Wave-power potential along the coast of the Province of Buenos Aires, Argentina. Energy, Washington, 17:997-1006.

López Gappa, J. J.; Tablado, A. \& Magaldi, N. H. 1990. Influence of sewage pollution on a rocky intertidal community dominated by the mytilid Brachydontes rodriguezii. Mar. Ecol. Progr. Ser., Oldendorf, 63:163-175.

1993. Seasonal changes in an intertidal community affected by sewage pollution. Environ. Pollut., Oxford, 82:157-165.

Olivier, S. R.; Escofet, A. et al. 1966. Contribución al conocimiento de las comunidades bénticas de Mar del Plata. I. El litoral rocoso entre Playa Grande y Playa Chica. An. Comn Invest. Cient. Prov. B. Aires, Buenos Aires, 7:185-206.

Orensanz, J. M. \& Estivariz, M. C. 1971. Los anélidos poliquetos de aguas salobres de la Provincia de Buenos Aires. Revta Mus. La Plata, Zool., La Plata, 11(98):95-114.

Otway, N. M.; Gray, C. A. et al. 1996. Assessing the impacts of deepwater outfalls on spatially- and temporally-variable marine communities. Mar. Environ. Res., Oxford, 41:45-71.

Pearson, T. H. \& Rosenberg, R. 1978. Macrobenthic succession in relation to organic enrichment and pollution of the marine environment. Oceanogr. Mar. Biol. Ann. Rev., Aberdeen, 16:229-311.

Penchaszadeh, P. 1973. Ecología de la comunidad del mejillín (Brachidontes rodriguezii, D’orb.) en el mediolitoral rocoso de Mar del Plata (Argentina): el proceso de recolonización. Physis, Serie A, Buenos Aires, 32(84):51-64.

Pocklington, P. \& Wells, P. G. 1992. Polychaetes. Key taxa for marine environmental quality monitoring. Mar. Pollut. Bull., Oxford, 24:593-598.

Ragnarsson, S. A. \& Rafaelli, D. 1999. Effects of the mussel Mytilus edulis L. on the invertebrate fauna of sediments. J. exp. Mar. Biol. Ecol., Amsterdam, 241:31-43.

Reish, D. J. 1972. The use of marine invertebrates as indicators of varying degrees of marine pollution. In: Ruivo, M. ed. Marine Pollution and Sea Life. London, Fishing News Books. p.203-207.

Reish, D. J. \& Gerlinger, T. V. 1997. A review of the toxicological studies with polychaetous annelids. Bull. mar. Sci., Miami, 60:584-607.

Rhoads, D. C. \& Boyer, L. F. 1982. The effects of marine benthos on physical properties of sediments. A successional perspective. In: McCall, P. L. \& Tevesz, M. J. S. eds. Animalsediment relations. Yale, Plenum. c. 1, p.3-52.

RygGS, B. 1985. Distribution of species along pollution-induced diversity gradients in benthic communities in Norwegian Fjords. Mar. Pollut. Bull., Oxford, 16:469-474.

Scelzo, M. A.; Elías, R. et al. 1996. Variación estacional de la estructura comunitaria del bivalvo intermareal Brachidontes rodriguezii (D’Orbigny, 1846) en sustratos artificiales (Mar del Plata, Argentina). Nerítica, Curitiba, 10:87-102.

Svane, I. \& Setyobudiandi, I. 1996. Diversity of associated fauna in beds of the blue mussel Mytilus edulis L.: effects of location, patches size, and position within a patch. Ophelia, Helsingor, 45:39-53.

TsuchiYa, M. \& NishiniRa, M. 1985. Islands of Mytilus as a habitat for small intertidal animals: effect of island size on community structure. Mar. Ecol. Progr. Ser., Oldendorf, 25:71-81.

Tsutsumi, H. 1990. Population persistence of Capitella sp. (Polychaeta; Capitellidae) on a mud flat subject to environmental disturbance by organic enrichment. Mar. Ecol. Progr. Ser., Oldendorf, 63:147-156.

Vallarino, E. A.; Rivero, M. S. et al. 2002. The community-level response to sewage impact in intertidal mussel beds of the Southwestern Atlantic and the use of the Shannon index to assess pollution. Revta Biol. mar. Oceanogr., Valparaíso, 37(1):25-33.

Walkley, A. \& Black, C. A. 1965. Organic carbon. In: Black, C. A. ed. Method of soils analysis. Madison, American Society of Agronomy. c. 4, p.1372-1375.

Recebido em 06.09.2002; aceito em 08.05.2003. 